supply. The rural schemes already installed prove that an overhead distribution at 11,000 volts $(11 \mathrm{kv}$.) is economical when the loads are small. When heavier loads are anticipated, $33 \mathrm{kv}$. is generally adopted. In a paper by $R$. Dean read to the Institution of Electrical Engineers on May 15, the available data relating to rural design have been collected and the many numerical tables given will enable engineers to obviate many tedious calculations. Official regulations and a number of practical details in design are also given. For rural supply, it has been found that wood poles are the best. Both concrete and steel poles are about 12 per cent more expensive. The admissible factor of safety for wood poles has now been reduced to $3 \cdot 5$. At the time of constructing the $132 \mathrm{kv}$. grid, steel-cored aluminium was the most popular conductor to use, but the author's tables show that copper-cored steel or steel-cored copper provide rather cheaper lines. The requisite experience has not yet been obtained of the effects of electrochemical action on these lines after a number of years exposure to the weather. There are many subsidiary advantages in favour of steel-cored aluminium for high-voltage lines.

\section{Prof. Patrick Abercrombie}

THe University of Liverpool gave London its first professor of town planning in Prof. S. D. Adshead, who has held the chair of town planning in the Bartlett School of Architecture at University College since 1914. The University of London is fortunate in securing as his successor Prof. Patrick Abercrombie, who since 1915 has been Lever professor of civic design at Liverpool. During these last twenty years he has been engaged in educating town planners, and has himself been a leader in every movement for the improvement and preservation of town and country alike. His interest in planning is not confined to town and industrial areas : he was one of the three mainly concerned in the founding of the Council for the Preservation of Rural England, and his work there has shown the necessity of proceeding by country preservation to country planning, and finally to national planning. $\mathrm{He}$ has recently been appointed to prepare the plans for a national park in Snowdonia. The series of town planning schemes published by the University Press of Liverpool, the Town Planning Review started in 1910 and issued for the last twenty-five years under his editorship, form a fine written and pictorial record not only of the work of Prof. Abercrombie himself, but also of all those who have devoted themselves to these problems during recent years.

\section{Health of the Army during 1933}

Lieut.-Gen. J. A. Hartigan, Director-General of the Army Medical Services, details in his first report, recently issued, the health of the Army at home and abroad for the year 1933. (H.M. Stationery Office. $2 s .6 d$. net.) The total strength at home and abroad was 184,000 men. The general health of all ranks fell little short of the high level reached in 1932, some increase in the admission rate being almost wholly accounted for by an increase in the incidence of influenza. The chief causes of death were injury, tuberculosis, pneumonia and suicide, and of invaliding, tuberculosis and inflammation of the middle ear. Venereal diseases have again diminished, but tonsillitis still claims a number of victims and has slightly increased. The admissions for diphtheria show a welcome reduction, and it is remarked that at the depots at Caterham and Woolwich, where Schick testing and immunisation when necessary are carried out as a routine, the disease is practically nonexistent. In addition to the statisties, details are given of the various measures that are being adopted at home and abroad for the prevention of disease.

\section{Conference on Atmospheric Pollution}

THIRTy-sIX representatives of local authorities and other organisations co-operating with the Department of Scientific and Industrial Research in the investigation of atmospheric pollution met on May 27 in the half yearly conference on atmospheric pollution at the offices of the Department. A report was received from Dr. G. M. B. Dobson on the progress of the researches carried out under the Atmospheric Pollution Research Committee. Dr. Dobson informed the conference that a full-time investigator has been appointed by the Department as a preliminary to the undertaking of an intensive survey, at a selected centre, of various types of pollution with a larger number of instruments. The method developed at the Building Research Station for estimating sulphur in the atmosphere is now being adopted more widely by the local authorities. Further experiments combined with weather observations are being taken in hand to facilitate the interpretation of the data collected by means of the deposit gauge observations.

\section{Lister Institute of Preventive Medicine}

Aт the general meeting of the members of the Lister Institute of Preventive Medicine, which was held on May 21, the governing body presented the Institute's forty-first annual report. This report contains an excellent summary of the important research work carried out in the laboratories and Serum Department during the past year. The amount of research seems to be more voluminous than usual, and the list of eommunications published occupies several pages. With the aid of a grant of $£ 3,400$ by the Rockefeller Foundation, a Svedberg velocity and equilibrium centrifuge is to be installed, a new and valuable equipment that should find useful application in protein, virus and other researches.

\section{Czechoslovak Institute for the Study of Sound}

AN institute for the study of sound has just been established in Prague under the management of Profs. K. Teige, M. Seemen and V. Vojtěch. The purpose of the institute will be to bring together scientific and practical workers to investigate sound in its physical, technical and physiological aspects. In pursuit of these aims it is proposed to arrange inquiries, excursions, lectures, both scientific and popular, and to carry out experiments and publish the results. The first important step to be taken in this connexion will be the equipment of a research 
laboratory, and one of the first tasks of the institute will be to investigate noise and the methods of dealing with it. Another subject for early inquiry will be the technique of musical instruments.

\section{Announcements}

The Langley Medal for aerodromics of the Smithsonian Institution was presented on May 21 to Dr. Joseph S. Ames, of Johns Hopkins University, who is chairman of the National Advisory Committee for Aeronautics. The award was made "in recognition of the surpassing improvement of the performance, efficiency, and safety of American aircraft resulting from the fundamental scientific researches conducted by the National Advisory Committee for Aeronautics under the leadership of Dr. Ames".

THE Executive Council of the Universities Bureau of the British Empire has had before it nine nomina. tions from Conferences of Universities overseas for the Carnegie Corporation Grants to the value of $£ 400$ each for the year 1935-36. A Selection Committee scrutinised these nominations and on May 25 the Executive Council approved the decision of this Committee to award these grants to Prof. T. J. Haarhoff, of the University of the Witwatersrand, Prof. T. H. Laby, of the University of Melbourne and Prof. Meghnad Saha, of the University of Allahabad.

THE curators of the Dr. Martini fund have awarded the 1935 prize of 1,000 gold marks to Dr. Carl, a former assistant at the Friedrichberg State Hospital, and at present senior physician in the serological and bacteriological department of the hospital, for a work on adenylacid metabolism in normal persons and the insane and in the brain of animals.

THE annual visitation of the National Physical Laboratory, Teddington, Middlesex, will take place on Tuesday, June 25, at 3-6 p.m.

AT the annual general meeting of the British Science Guild, to be held on June 12 at 4.30 p.m., a lecture on "Gas Defence" will be given by Mr. J. Davidson Pratt, general manager and secretary of the Association of British Chemical Manufacturers. The meeting will take place in the lecture theatre of the Royal Society of Arts, John Street, Adelphi, London, W.C.2, and tickets (for which there is no charge) may be obtained on application to the Secretary of the British Science Guild, 6 John Street, Adelphi, London, W.C.2.

THE fourteenth annual congress known as the Journeés médicales de Bruxelles will be held at Brussels from June 29-July 3, that is, while the International Exhibition is still open. The inaugural address will be delivered by Prof. Loeper, of Paris, on music and medicine. The subscription is 100 francs. Further information can be obtained from the general secretary, Dr. René Beckers, 141 rue Belliard, Brussels.

Messrs. Wheldon and Westey have recently issued Catalogue No. 40 of books, periodicals and pamphlets on geology, palæontology, mineralogy and mining. Upwards of 1,300 items are listed, including many older works of historical interest. Among the periodicals may be mentioned an exceptionally long run of the Annales des Mines, from its commencement in 1795 (as the Journal des Mines) down to 1918. There is also listed a large number of the Memoirs of the Geological Survey of Great Britain, and of the bulletins and monographs of the United States Geological Survey. The pamphlets include many extracted from early volumes of the Philosophical Transactions of the Royal Society.

Applications are invited for the following appointments, on or before the dates mentioned :-An engineer at the Building Research Station, Garston, near Watford-The Establishment Officer, Department of Scientific and Industrial Research, 16 Old Queen Street, Westminster, S.W.1 (June 4). A lecturer in mechanical engineering in the St. Helens Municipal Technical School--The Secretary for Education, Education Office, St. Helens (June 7). A temporary demonstrator in botany in the University College of Wales, Aberystwyth-The Secretary (June 8). A lecturer in mining in the Heanor Mining and Technical School-W. G. Briggs, Director of Education, Derby (June 8). A lecturer in mathematics in Merchant Venturers' Technical College, Bristol-The Registrar (June 11). A junior in the Records Section of the Fuel Research Station, East Greenwich-The Establishment Officer, Department of Scientific and Industrial Research, 16 Old Queen Street, Westminster, S.W.1 (June 11). A lecturer in the Department of Civil and Mechanical Engineering, King's College, Strand, London, W.C.2-The Secretary (June 12). A woman lecturer in biology and the teaching of biology in the Department of Education, University of Birmingham-The Secretary (June 13). A lecturer in mathematics, a lecturer in science and a lecturer in general education at the Royal Military Academy, Woolwich-The UnderSecretary of State (C.5), The War Office, London, S.W.1 (June 15). A lecturer in mathematics, a lecturer in botany and a lecturer in physiology in the Chelsea Polytechnic, London, S.W.3-The Principal (June 15). A Curator of the Public Museum and Art Gallery, Hastings-The Director of Education, 18 Wellington Square, Hastings (June 15). A lecturer in physics and mathematics in the Northampton Polytechnic, St. John Street, London, E.C.1-The Principal (June 21). A lecturer in botany at the Imperial College of Science and Technology, London, S.W.7-The Secretary (June 22). An assistant lecturer in chemistry in the University of Sheffield-The Registrar (June 22). A lecturer in electrical engineering at Loughborough College-The Registrar (June 30). Two University demonstrators in pathology in the University of Cambridge-Prof. H. R. Dean (July 10). A part-time demonstrator in chemistry in the London (Royal Free Hospital) School of Medicine for Women -The Warden, 8 Hunter Street, Brunswick Square, W.C.1. A lecturer in civil engineering and building in the Portsmouth Municipal College-The Registrar. 